PLPB: Pendidikan Lingkungan dan Pembangunan Berkelanjutan

DOI: https://doi.org/10.21009/PLPB.162.01

DOI: 10.21009/PLPB

\title{
PENGARUH PENGETAHUAN TENTANG LINGKUNGAN HIDUP, KEARIFAN LOKAL, LOCUS OF CONTROL, DAN MOTIVASI BERTANI TERHADAP PERILAKU LINGKUNGAN YANG BERTANGGUNG JAWAB PETANI DI KABUPATEN SOPPENG
}

\author{
Mulyadi \\ DOSEN PASCASARJANA UNIVERSITAS NEGERI MAKASSAR \\ Email: mulyadi1959@yahoo.com
}

\begin{abstract}
Responsible environmental behavior is assumed to be significantly affected bay one's knowledge of the environment, the local wisdom, locus of control motivation farming. The study reported here aimed to examine how the four independent variables actually affected the level of farmers' responsible behavior towards environment. The causal and multidimensional social study was conducted in the Soppeng Regency of South Sulawesi from July 2009 to October 2009, trough a survey to the paddy farmers in the Liliriaja District. A sample of 120 farmers was made up 30 randomly selected farmers from each of the four purposefully selected sub districts in Liliriaja: Appanang, Galung, Rompegading and Jampu. The data of each variable were collected separately with a questionnaire. A path technique, which was preceded by normality and variance homogeneity tests, was employed to analyze the data descriptively and inferentially. The results proved that the farmers' farming motivation and their responsible environmental behavior, respectively, was directly affected by their knowledge of the environment, the local wisdom, and the locus of control. The three independent variables also indirectly affected the farmers' responsible environmental behavior through their motivation in farming. These findings suggest that the variables of environmental knowledge, local wisdom, locus of control and the farmers' motivation in farming are important determinants of their responsible environmental behavior. Variation in the farmers' responsible environmental behavior may therefore be minimized by improved knowledge of the environment, local wisdom, locus of control and farming motivation.
\end{abstract}

Keyword: knowledge of the environment, local wisdom, locus of control, farming motivation. 


\section{Pendahuluan}

Pertumbuhan penduduk yang cepat dan situasi ekonomi politik yang tidak menentu pada tahun 1960-an mengakibatkan Indonesia mengalami kekurangan pangan. Untuk mengatasi kekurangan pangan tersebut, pemerintah menetapkan kebijakan tentang Ketahanan Pangan atau dulu dinamakan program Swasembada Beras. Seiring dengan itu, peningkatan produksi padi secara cepat dapat dicapai dengan penerapan teknologi pertanian modern yang dikenal sebagai teknologi "Revolusi Hijau".

Keberhasilan pertanian revolusi hijau ditunjang berbagai kemudahan fasilitas pertanian diberikan kepada petani. Fasilitas seperti: pupuk, bibit unggul, obat-obatan pertanian, kredit usaha tani, dan lain-lain. Dibalik keberhasilan tersebut, masalah baru yang dihadapi yakni: produktivitas lahan menurun, kesuburan tanah menurun, pencemaran dan kerusakan lingkungan meningkat. Hal ini sebagai akibat dari perilaku petani yang bergantung pada pemerintah. Petani tidak dapat mengembangkan potensi dan kreativitas yang dimiliki, bahkan kearifan lokal yang ada semakin pudar.

Kurangnya kesadaran petani dalam menata kelestarian lingkungan merupakan salah satu penyebab terjadinya krisis lingkungan yang berkelanjutan. Krisis lingkungan yang terjadi akhir-akhir ini, bersumber dari kesalahan perilaku manusia terhadap cara pandang dan kesalahan eksplorasi sumber daya alam. Sejalan dengan Chiras (1991) bahwa kerusakan lingkungan disebabkan oleh ulah manusia yang bermental frontier. Ciri manusia bermental frontier adalah: (1) Berpandangan bahwa sumber kekayaan alam tidak terbatas; (2) Berpandangan bahwa manusia bukan bagian dari alam; dan (3) Berpandangan bahwa alam ada untuk dikuasai dan digunakan dalam memenuhi kebutuhan hidup manusia. Sedangkan, Billon (2001); Porto (2002) menyatakan kerakusan dan ketamakan merupakan salah satu sifat buruk manusia yang secara sengaja atau tidak dapat muncul dalam perilaku hubungan manusia dengan alam, maupun manusia dengan manusia lainnya. Konflik lingkungan yang ditimbulkan dari penguasaan sumberdaya alam lebih dipicu oleh nafsu tamak dan rakus, yang berakibat pada diskriminasi, ketidakadilan, dan marjinalisasi kepentingan masyarakat lain.

Upaya pelestarian lingkungan atau pengembangan sistem pengelolaan lingkungan hidup secara berkelanjutan, maka aspek perilaku manusia dan kearifan-kearifan lokal perlu diperhatikan. Hal ini telah ditegaskan dalam Undang-Undang Nomor 32 tahun 2009 tentang Perlindungan dan Pengelolaan Lingkungan Hidup mengenai pentingnya budaya masyarakat setempat, kearifan lokal, dan peran serta masyarakat dalam pengambilan keputusan dan pelaksanaan perlindungan dan pengelolaan lingkungan hidup baik secara langsung maupun tidak langsung.

Permasalahan krisis lingkungan seperti diuraikan di atas juga terjadi di Kabupaten Soppeng. Kabupaten Soppeng adalah salah satu wilayah agraris dan termasuk daerah penghasil beras di Provinsi Sulawesi Selatan dengan produksi gabah sebanyak 213.703 ton pada tahun 2007. Jumlah penduduk 227.273 jiwa dan 59.601 jiwa diantaranya adalah petani atau $67 \%$ dari total angkatan kerja 88.547 jiwa. Karakteristik petani pada umumnya
Volume XVI
Nomor 02
September 2015 
mempunyai tingkat pendidikan formal yang rendah, yaitu sekolah dasar atau sederajat. (BPS Soppeng, 2008).

Wawancara dengan beberapa tokoh masyarakat di Kabupaten Soppeng (Agustus 2008), diperoleh informasi bahwa telah terjadi perubahan pola bertani. Penerapan nilai-nilai kearifan lokal dalam bertani yang biasanya dilakukan secara turun-temurun oleh petani jarang lagi terlihat, seperti kegiatan dalam bentuk ritual untuk melindungi dan mengelola lingkungan hidup agar tetap lestari dan sebagai penghormatan kepada sang pencipta. Selain itu, gotong-royong yang merupakan ciri khas masyarakat pedesaan mulai pudar. Hal ini sebagai akibat dari kebijakan pemerintah yang cenderung hanya berorientasi pada peningkatan produksi. Jadi, perilaku petani di Kabupaten Soppeng sangat bergantung kepada kebijakan pemerintah, seperti ketergantungan pada pupuk dan obat-obatan pertanian yang sebagian besar berdampak terhadap kerusakan lingkungan. Untuk itu, perilaku lingkungan bertanggung jawab petani perlu ditingkatkan dengan memperhatikan faktor-faktor yang mempengaruhinya. Faktor-faktor yang mempengaruhi perilaku yang bertanggung jawab oleh Hanggerford dan Volk (1990) mengemukakan antara lain pengetahuan tentang isu, keterampilan bertindak, keinginan bertindak, faktorfaktor situasional, dan faktor kepribadian seperti sikap, locus of control dan tanggung jawab pribadi, serta adanya niat atau keinginan untuk bertindak (Intention to act).

Berdasarkan fenomena di atas, maka rumusan masalah dalam penelitian ini adalah apakah terdapat pengaruh langsung pengetahuan tentang lingkungan hidup, kearifan lokal, locus of control, dan motivasi bertani terhadap perilaku lingkungan yang bertanggung jawab petani di Kabupaten Soppeng. Untuk menjawab permasalahan tersebut, maka beberapa kajian teoritis tentang perilaku, kearifan lokal, locus of control dan motivasi bertani yang menjadi acuan dalam penelitian ini.

\section{Metodologi Penelitian}

Penelitian ini dilaksanakan di Kabupaten Soppeng Provinsi Sulawesi Selatan selama 6 (enam) bulan, yaitu mulai Juni 2009 sampai dengan November 2009. Metode yang digunakan adalah metode kausal dengan analisis jalur (path analysis). Variabel-variabel yang akan dikaji dalam penelitian ini adalah: (1) Pengetahuan tentang lingkungan hidup; (2) Kearifan lokal; (3) Locus of control; (4) motivasi bertani; dan (5) Perilaku lingkungan yang bertanggung jawab.

Populasi target dalam penelitian ini adalah petani yang mengolah sawah, yaitu yang mengusahakan tanaman padi atau tanaman palawija di Kabupaten Soppeng. Sedangkan populasi terjangkau adalah petani yang tinggal di Kecamatan Liliriaja. Jumlah anggota sampel 120 orang dengan metode simple random sampling.

Teknik analisis data menggunakan analisis deskriptif dan analisis inferensial. Analisis deskriptif yang digunakan dalam penyajian data, ukuran data, ukuran sentral, serta ukuran penyebaran. Penyajian data mencakup daftar distribusi dan histogram. Ukuran sentral meliputi mean, median dan modus. Ukuran penyebarannya berupa varians dan simpangan baku atau standar deviasi.

Analisis inferensial digunakan untuk menguji hipotesis dengan memakai analisis jalur (path analysis) yang didahului dengan uji normalitas serta uji homogenitas varians. Pengaruh langsung dan tidak langsung dari variabel eksogen
Volume XVI
September 2015

ISSN 1411-1829 
terhadap suatu variabel endogen dapat diketahui dengan melihat koefisien jalur.

Persyaratan analisis dan uji linieritas yang digunakan adalah uji normalitas dan uji homogenitas varians. Normalitas data menggunakan uji Kolmogorov Smirnov, sedangkan homogenitas varians menggunakan uji Bartlett dan uji linieritas dilakukan dengan menggunakan uji Anava (uji F).

Proses pengujian hipotesis penelitian digunakan analisis jalur dengan terlebih dahulu menghitung koefisien korelasi antarvariabel, dilanjutkan dengan menghitung masing-masing kofisien jalurnya.

\section{Hasil Penelitian Dan Pembahasan}

1. Pengaruh langsung Pengetahuan tentang lingkungan hidup terhadap Motivasi bertani

Berdasarkan hasil analisis jalur Pengetahuan tentang lingkungan hidup $\left(\mathrm{X}_{1}\right)$ terhadap Motivasi bertani $\left(\mathrm{X}_{4}\right)$ diperoleh koefisien jalur $\rho 41$ sebesar 0,263 dengan $t_{\text {hitung }}=4,314$, sedangkan $t_{\text {tabel }}=2,359(\alpha=0,05 ; \mathrm{dk}=116)$. Karena nilai $t_{\text {hitung }}>t_{\text {tabel }}$, maka terdapat pengaruh langsung positif Pengetahuan tentang lingkungan hidup terhadap Motivasi bertani. Besar kontribusi yang diberikan variabel $\mathrm{X}_{1}$ terhadap $\mathrm{X}_{4}$ sebesar: $(0,263)^{2}$ x $100=6,92 \%$. Temuan penelitian dapat diartikan tinggi rendahnya motivasi bertani salah satunya dipengaruhi oleh pengetahuan tentang lingkungan hidup. Dengan demikian, pengetahuan tentang lingkungan hidup menyebabkan perubahan terhadap motivasi bertani. Hal ini sesuai pendapat Gagne (1997) menyatakan bahwa pengetahuan adalah kerangka informasi mengenai fakta-fakta yang tersusun secara teratur sehingga mempunyai arti atau makna dan dapat diterapkan. Pengetahuan tersebut tersimpan dalam ingatan dan dapat digali atau dapat diingat kembali pada saat dibutuhkan. Oleh karena itu, pengetahuan terbentuk setelah seseorang melakukan pengamatan melalui alat-alat indranya terhadap berbagai fenomena lingkungan, selanjutnya mengelola berbagai pengalaman yang diperoleh dalam lingkup kognitif menjadi informasi yang tersusun secara teratur dan bermakna yang tersimpan dalam memori. Pengetahuan lingkungan yang dimiliki petani dapat menjadi pedoman dan kekuatan timbulnya motivasi bertani.

2. Pengaruh langsung Pengetahuan tentang lingkungan hidup terhadap Perilaku lingkungan yang bertanggung jawab petani

Berdasarkan hasil analisis jalur Pengetahuan tentang lingkungan hidup $\left(\mathrm{X}_{1}\right)$ terhadap Perilaku lingkungan yang bertanggung jawab pada petani $\left(\mathrm{X}_{5}\right)$ diperoleh koefisien jalur $\rho 51$ sebesar 0,158 dengan $t_{\text {hitung }}=2,562$, sedangkan $\mathrm{t}_{\text {tabel }}=2,358(\alpha=0,05 ; \mathrm{dk}=115)$. Karena nilai $t_{\text {hitung }}>t_{\text {tabel }}$, maka terdapat pengaruh langsung positif Pengetahuan tentang lingkungan hidup terhadap Perilaku lingkungan yang bertanggung jawab petani. Besar kontribusi yang diberikan variabel $\mathrm{X}_{1}$ terhadap $\mathrm{X}_{4}$ sebesar: $(0,158)^{2}$ x $100=2,50 \%$. Temuan penelitian dapat diartikan tinggi rendahnya perilaku lingkungan yang bertanggung jawab petani salah satunya dipengaruhi oleh pengetahuan tentang lingkungan hidup. Dengan demikian, pengetahuan tentang lingkungan hidup menyebabkan perubahan terhadap perilaku lingkungan yang bertanggung jawab petani. Hal ini diperkuat oleh Ancok (1997) bahwa dengan adanya pengetahuan yang baik tentang suatu hal, akan mendorong terjadinya perubahan perilaku.

3. Pengaruh langsung Kearifan lokal terhadap Motivasi bertani

\section{Volume XVI}


Berdasarkan hasil analisis jalur Kearifan lokal $\left(\mathrm{X}_{2}\right)$ terhadap Motivasi bertani $\left(\mathrm{X}_{4}\right)$ diperoleh koefisien jalur $\rho 42$ sebesar 0,249 dengan $t_{\text {hitung }}=4,318$, sedangkan $\mathrm{t}_{\text {tabel }}=2,359(\alpha=0,05 ; \mathrm{dk}=$ 116. Karena nilai $t_{\text {hitung }}>t_{\text {tabel }} \alpha=0,05$, maka terdapat pengaruh langsung positif Kearifan lokal terhadap Motivasi bertani. Besar kontribusi yang diberikan variabel $\mathrm{X}_{2}$ terhadap $\mathrm{X}_{4}$ sebesar: $(0,249)^{2} \times 100=$ $6,20 \%$. Temuan penelitian ini dapat diartikan tinggi rendahnya motivasi bertani salah satunya dipengaruhi oleh kearifan lokal. Dengan demikian, kearifan lokal menyebabkan perubahan terhadap motivasi bertani.

4. Pengaruh positif Kearifan lokal terhadap Perilaku lingkungan yang bertanggung jawab petani

Berdasarkan hasil analisis jalur Kearifan lokal $\left(\mathrm{X}_{2}\right)$ terhadap Perilaku lingkungan yang bertanggung jawab $\left(\mathrm{X}_{5}\right)$ diperoleh koefisien jalur $\rho 52$ sebesar 0,184 dengan $t_{\text {hitung }}=3,143$, sedangkan $\mathrm{t}_{\text {tabel }}=2,358(\alpha=0,05 ; \mathrm{dk}=115)$. Karena nilai $t_{\text {hitung }}>t_{\text {tabel }}$, maka terdapat pengaruh positif Kearifan lokal terhadap Perilaku lingkungan yang bertanggung jawab petani. Besar kontribusi yang diberikan variabel $\mathrm{X}_{2}$ terhadap $\mathrm{X}_{5}$ sebesar: $(0,184)^{2}$ x $100=3,39 \%$. Temuan penelitian dapat diartikan tinggi rendahnya perilaku lingkungan yang bertanggung jawab petani salah satunya dipengaruhi oleh kearifan lokal. Dengan demikian, kearifan lokal menyebabkan perubahan terhadap perilaku lingkungan yang bertanggung jawab petani. Hal ini sesuai pendapat Tiezzi, Marchettini, dan Rossini (1995), bahwa kearifan lokal merupakan pengetahuan yang eksplisit, muncul dari periode panjang yang berevolusi bersama-sama masyarakat dan lingkungannya dalam sistem lokal yang sudah dialami bersama-sama. Dengan proses evolusi tersebut menjadikan kearifan lokal sebagai sumber energi potensial dari sistem pengetahuan kolektif masyarakat untuk hidup bersama secara dinamis dan damai. Kearifan lokal menjadi acuan tingkahlaku seseorang dalam kehidupan masyarakat yang penuh keadaban termasuk dalam melestarikan lingkungan. Ostrom (1993) kearifan lokal sebagai kekuatan dan kemampuan potensial menuntun perilaku masyarakat dalam kehidupan komunitasnya.

5. Pengaruh langsung Locus of control terhadap Motivasi bertani

Berdasarkan hasil analisis jalur Locus of control $\left(\mathrm{X}_{3}\right)$ terhadap Motivasi bertani $\left(\mathrm{X}_{4}\right)$ diperoleh koefisien jalur $\rho_{43}$ $=0,488$ dengan $t_{\text {hitung }}=7,534$, sedangkan $\mathrm{t}_{\text {tabel }}=2,359(\alpha=0,05 ; \mathrm{dk}=116)$. Karena nilai $t_{\text {hitung }}>t_{\text {tabel }}$, maka terdapat pengaruh langsung positif Locus of control terhadap Motivasi bertani. Besar kontribusi yang diberikan variabel $\mathrm{X}_{3}$ terhadap $\mathrm{X}_{4}$ sebesar: $(0,488)^{2}$ × $100=$ $23,81 \%$. Temuan penelitian ini dapat diartikan tinggi rendahnya motivasi bertani salah satunya dipengaruhi oleh locus of control. Dengan demikian, locus of control menyebabkan perubahan terhadap motivasi bertani. Robbin (1994) locus of control mengarah pada kemampuan seseorang dalam mempengaruhi kejadian yang berhubungan dengan hidupnya. Bila seseorang mempunyai locus of control eksternal, itu berarti bahwa ia percaya akan kekuatan lingkungan sekitarnya dalam mengendalikan nasibnya. Sebaliknya locus of control internal menggambarkan kemampuan seseorang menghadapi ancaman yang timbul dari lingkungannya. Selanjutnya dikatakan bahwa yang mempengaruhi locus of control dari seseorang antara lain : 1) keyakinan, 2) budaya, 3) lingkungan. Ketiga faktor tersebut mempengaruhi locus of control dari seseorang. Adanya locus of control yang dimiliki petani akan menjadi kekuatan dalam mendorong motivasinya dalam bertani.
Volume XVI
September 2015

ISSN 1411-1829 
6. Pengaruh langsung Locus of control terhadap Perilaku lingkungan yang bertanggung jawab petani

Berdasarkan hasil analisis jalur Locus of control $\left(\mathrm{X}_{3}\right)$ terhadap Perilaku lingkungan yang bertanggung jawab $\left(\mathrm{X}_{5}\right)$ diperoleh koefisien jalur $\rho 53=0,205$ dengan $\mathrm{t}_{\text {hitung }}=2,747$, sedangkan $\mathrm{t}_{\text {tabel }}=$ $2,358(\alpha=0,05 ; \mathrm{dk}=115)$. Karena nilai $t_{\text {hitung }}>\mathrm{t}_{\text {tabel }}$, maka terdapat pengaruh langsung positif Locus of control terhadap Perilaku lingkungan yang bertanggung jawab petani. Besar kontribusi yang diberikan variabel $\mathrm{X}_{3}$ terhadap $\mathrm{X}_{5}$ sebesar: $(0,205)^{2}$ x $100=$ $4,20 \%$. Temuan penelitian ini dapat diartikan tinggi rendahnya perilaku lingkungan yang bertanggung jawab petani salah satunya dipengaruhi oleh locus of control. Dengan demikian, locus of control menyebabkan perubahan terhadap perilaku lingkungan yang bertanggung jawab petani. Hal ini dapat dilihat dari pendapat Carry (1993) perilaku lingkungan dipengaruhi oleh berbagai faktor, seperti: norma subjektif, keyakinan berperilaku, dan adanya kontrol yang berasal dari sumber perilaku serta kesempatan. Penner dalam Cooper dan Payne (1991) bahwa individu dengan orientasi internal dan eksternal mempunyai pandangan dunia yang berbeda. Perbedaan ini tampak dalam tingkah laku sosialnya, kehidupan mereka yang diatur oleh faktor-faktor di luar kontrolnya, memiliki usaha yang kurang dalam mengendalikan lingkungannya dibandingkan dengan orang-orang yang memilki kontrol internal. Hal ini disebabkan karena seseorang dengan kontrol internal percaya bahwa ia dapat merubah lingkungan yang dirasakan tidak memuaskan. Dengan demikian, orang yang memiliki kontrol internal lebih dapat menyesuaikan diri dengan lingkungan dan perubahan yang terjadi dalam lingkungan tersebut. Selanjutnya, Rae Andre (2008) menyatakan locus of control sebagai tingkatan kepercayaan seseorang terhadap tindakan-tindakan yang mempengaruhi hasil-hasilnya, penghargaan dan penguatan-penguatan yang dihasilkannya, di dalam kehidupan sehari-hari apakah dipandang karena tindakan sendiri atau karena faktor lingkungan yang tidak dapat dikontrol. Larsen dan Bush (2002), bahwa locus of control menggambarkan seberapa jauh seseorang memandang hubungan antara perbuatan yang dilakukannya (action) dengan akibat/hasilnya (outcome). Dengan locus of control internal yang dimiliki petani akan menjadi kekuatan dalam mewujudkan perilaku lingkungan yang bertanggung jawab petani mengelola lahan pertanian secara berkelanjutan.

7. Pengaruh langsung Motivasi bertani terhadap Perilaku lingkungan yang bertanggung jawab petani

Berdasarkan hasil analisis jalur Motivasi bertani $\left(\mathrm{X}_{4}\right)$ terhadap Perilaku lingkungan yang bertanggung jawab $\left(\mathrm{X}_{5}\right)$ diperoleh koefisien jalur $\rho_{54}=0,451$ dengan $\mathrm{t}_{\text {hitung }}=5,155$, sedangkan $\mathrm{t}_{\text {tabel }}=$ $2,358(\alpha=0,05 ; \mathrm{dk}=115)$. Karena nilai $t_{\text {hitung }}>t_{\text {tabel }}$, maka terdapat pengaruh langsung positif Motivasi bertani terhadap Perilaku lingkungan yang bertanggung jawab petani. Besar kontribusi yang diberikan variabel $\mathrm{X}_{4}$ terhadap $\mathrm{X}_{5}$ sebesar: $(0,451)^{2}$ × $100=$ 
20,34 \%. Temuan penelitian ini dapat diartikan tinggi rendahnya perilaku lingkungan yang bertanggung jawab petani salah satunya dipengaruhi oleh motivasi bertani. Dengan demikian, motivasi bertani menyebabkan perubahan terhadap perilaku lingkungan yang bertanggung jawab petani. Hal ini diperkuat oleh pendapat Wahosumidjo (1992), Berliner dan Robert (1996) bahwa motivasi merupakan kekuatan yang mendorong seseorang untuk melakukan sesuatu untuk mencapai tujuan. Selanjutnya Gibson, Ivancevich, dan Donelly (2005) motivasi sebagai suatu kemampuan yang kita gunakan jika kita menguraikan kekuatan-kekuatan yang bekerja terhadap atau di dalam diri individu untuk memulai dan mengarahkan perilaku. Sejalan dengan Robbins, Judge (2009) dan Colquitt, Lepine, Wesson (2009) bahwa motivasi sebagai proses yang ikut menentukan intensitas, arah, dan ketekunan individu dalam usaha mencapai tujuan tertentu. Luthans (1995) menekankan peranan motivasi sebagai penggerak munculnya perilaku melalui tiga komponen psikologis yaitu: (1) kebutuhan (needs); (2) dorongan (drives); dan (3) insentif atau tujuan (goals). Jadi motivasi terjadi apabila seseorang mempunyai keinginan dan kemauan melakukan suatu kegiatan atau tindakan dalam rangka mencapai tujuan. Sehingga peran motivasi bertani dalam perilaku lingkungan yang bertanggung jawab dalam pertanian berkelanjutan sangat menentukan.

8. Pengaruh secara bersama-sama Pengetahuan tentang Lingkungan
Hidup, Kearifan Lokal, dan Locus of Control terhadap Motivasi Bertani

Berdasarkan analisis diperoleh $\mathrm{F}_{\text {hitung }}=285,885$ dengan nilai probabilitas $(\mathrm{sig})=0,000$. Derajat bebas $\left(\mathrm{db}_{1}\right)=\mathrm{k}=3$ dan $\mathrm{db}_{2}=\mathrm{n}-\mathrm{k}-1=$ $120-3-1=116$. Nilai $F_{\text {tabel }}=2,674$ untuk $\alpha=0,05$. Karena nilai $F_{\text {tabel }}>$ $F_{\text {hitung }}$ atau 285,885 > 2,674, maka Pengetahuan tentang lingkungan hidup $\left(\mathrm{X}_{1}\right)$, Kearifan lokal $\left(\mathrm{X}_{2}\right)$, dan Locus of control $\left(\mathrm{X}_{3}\right)$ secara bersama berpengaruh positif terhadap Motivasi bertani $\left(\mathrm{X}_{4}\right)$.

Koefisien diterminan $\mathrm{R}_{\text {square }}=$ 0,881 atau $=88,1 \%$ dan besarnya pengaruh variabel lain $\mathrm{e}_{4}=\sqrt{ }(1-$ $0,881)=0,345=0,3452=0,119=11$, $9 \%$

9. Pengaruh secara bersama-sama Pengetahuan tentang lingkungan hidup $\left(\mathrm{X}_{1}\right)$, Kearifan lokal $\left(\mathrm{X}_{2}\right)$, Locus of Control $\left(\mathrm{X}_{3}\right)$, dan Motivasi Bertani $\left(\mathrm{X}_{4}\right)$ terhadap Perilaku Lingkungan yang Bertanggung Jawab $\left(\mathrm{X}_{5}\right)$

Berdasarkan analisis Dari Tabel Anova diperoleh nilai $F$ sebesar 218,946 dengan nilai probabilitas (sig) $=0,000$. Derajat bebas $\left(\mathrm{db}_{1}\right)=\mathrm{k}=4$ dan $\mathrm{db}_{2}=\mathrm{n}-\mathrm{k}-1=120-4-1=115$. Diperoleh nilai $F_{\text {tabel }}=2,443$ untuk $\alpha=$ 0,05 . Karena nilai $F_{\text {tabel }}>F_{\text {hitung }}$ atau 218,946 > 2,443, maka Pengetahuan tentang lingkungan hidup $\left(\mathrm{X}_{1}\right)$, Kearifan lokal $\left(\mathrm{X}_{2}\right)$, dan Locus of Control $\left(\mathrm{X}_{3}\right)$, Motivasi bertani $\left(\mathrm{X}_{4}\right)$ secara bersama berpengaruh positif terhadap Perilaku lingkungan yang bertanggung jawab pada petani $\left(\mathrm{X}_{5}\right)$.

Besarnya koefisien diterminan $\mathrm{R}_{\text {square }}=0,895$ atau $=89,5 \%$ dan besarnya pengaruh variabel lain $\mathrm{e}_{4}=$ $\sqrt{ }(1-0,895)=0,324=0,324^{2}=0,105$ $=10,5 \%$ 


\section{Pengaruh Tidak Langsung}

a. Pengaruh tidak langsung Pengetahuan tentang lingkungan hidup $\left(\mathrm{X}_{1}\right)$ melalui Motivasi bertani $\left(\mathrm{X}_{4}\right)$ terhadap Perilaku lingkungan yang bertanggung jawab $\left(\mathrm{X}_{5}\right)$

Koefisien parameter pengaruh tidak langsung Pengetahuan tentang lingkungan hidup $\left(\mathrm{X}_{1}\right)$ melalui Motivasi bertani $\left(\mathrm{X}_{4}\right)$ terhadap Perilaku lingkungan yang bertanggung jawab $\left(\mathrm{X}_{5}\right)$ sebesar 0,263 $\mathrm{x} 0,451=0,119$. Dengan demikian, kontribusi yang diberikan adalah sebesar $(0,119)^{2} \times 100 \%=1,42 \%$.

b. Pengaruh tidak langsung Kearifan lokal $\left(\mathrm{X}_{2}\right)$ melalui Motivasi bertani $\left(\mathrm{X}_{4}\right)$ terhadap Perilaku lingkungan yang bertanggung jawab $\left(\mathrm{X}_{5}\right)$

Koefisien parameter pengaruh tidak langsung Kearifan lokal $\left(\mathrm{X}_{2}\right)$ melalui Motivasi bertani $\left(\mathrm{X}_{4}\right)$ terhadap Perilaku lingkungan yang bertanggung jawab $\left(\mathrm{X}_{5}\right)$ sebesar 0,249 $\mathrm{x} 0,451=0,112$. Dengan demikian, kontribusi yang diberikan adalah sebesar $(0,112)^{2} \times 100 \%=1,25 \%$.

c. Pengaruh tidak langsung Locus of control $\left(\mathrm{X}_{3}\right)$ melalui Motivasi bertani $\left(\mathrm{X}_{4}\right)$ terhadap Perilaku lingkungan yang bertanggung jawab $\left(\mathrm{X}_{5}\right)$
Koefisien parameter pengaruh tidak langsung Locus of control $\left(\mathrm{X}_{3}\right)$ melalui Motivasi bertani $\left(\mathrm{X}_{4}\right)$ terhadap Perilaku lingkungan yang bertanggung jawab $\left(\mathrm{X}_{5}\right)$ sebesar $0,488 \times 0,451=0,112$. Dengan demikian, kontribusi yang diberikan adalah sebesar $(0,112)^{2} \times 100 \%=4$, $84 \%$.

\section{Pengaruh Total}

Berdasarkan model analisis jalur yang dijadikan sebagai acuan dari analisis penelitian ini diketahui pengaruh total, yaitu:

a. Pengaruh total $X_{1}$ terhadap $X_{5}$ sebesar 0,277 Kontribusi yang diberikan variabel $\mathrm{X}_{1}$ terhadap $\mathrm{X}_{5}$ adalah sebesar $(0,277)^{2} \times 100=7,67$ $\%$

b. Pengaruh total $X_{2}$ terhadap $X_{5}$ sebesar 0,296. Kontribusi yang diberikan variabel $\mathrm{X}_{2}$ terhadap $\mathrm{X}_{5}$ adalah sebesar $(0,296)^{2} \times 100=8,76$ $\%$

c. Pengaruh total $X_{3}$ terhadap $X_{5}$ sebesar 0,425. Kontribusi yang diberikan variabel $\mathrm{X}_{3}$ terhadap $\mathrm{X}_{5}$ adalah sebesar $(0,425)^{2} \times 100=$ $18,06 \%$

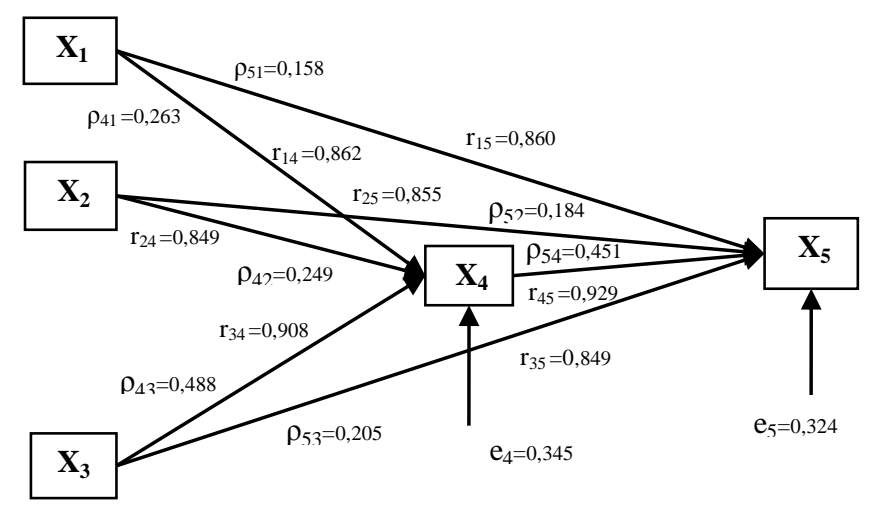

Gambar 1. Model Analisis Jalur Hasil Pengujian Hipotesis

Berdasarkan temuan-temuan disimpulkan bahwa perilaku lingkungan
penelitian di atas, maka dapat yang bertanggung jawab petani 
dipengaruhi secara langsung oleh pengetahuan tentang lingkungan hidup, kearifan lokal, locus of control dan motivasi bertani, baik secara sendirisendiri maupun secara bersama-sama. Selanjutnya, perilaku lingkungan yang bertanggung jawab petani dipengaruhi secara tidak langsung oleh pengetahuan tentang lingkungan hidup, kearifan lokal, locus of control melalui motivasi bertani. Temuan ini diperkuat oleh Hanggerford dan Volk (1990:10) tentang model perilaku lingkungan yang bertanggung jawab yang mengemukakan bahwa perilaku dipengaruhi oleh strategi penerapan pengetahuan, pengetahuan tentang isu, keterampilan bertindak, keinginan bertindak, faktor-faktor situasional, dan faktor kepribadian seperti sikap, locus of control dan tanggung jawab pribadi, serta adanya niat atau keinginan untuk bertindak (Intention to $a c t$ ). Faktor-faktor situasional, seperti kendala ekonomi, sosial, tekanan-tekanan dan kesempatan dapat memperkuat atau memperlemah variabel-variabel lain dalam model tersebut. Dari beberapa faktor yang mempengaruhi perilaku lingkungan tersebut merupakan variabel yang berpengaruh langsung ataupun tidak langsung melalui intention to act (keinginan bertindak atau berperilaku) terhadap perilaku lingkungan yang bertanggung jawab. Temuan penelitian juga didukung oleh temuan penelitian Koivisto (2008:140) tentang faktor yang mempengaruhi perilaku lingkungan bertanggung jawab pada sektor pelayanan di Finlandia, menemukan pengaruh langsung pengetahuan tentang lingkungan, sikap, norma subyektif terhadap perilaku yang bertanggung jawab. Donnart and Meyer (2005:2) mengemukakan terdapat empat tahap mengarah kepada tindakan atau perilaku, yaitu: variabel internal, motivasi, tujuan yang berorientasi kepada perilaku dan selanjutnya tindakan (action). Variabel internal berkaitan dengan personality, seperti locus of control, sikap, dan tanggung jawab pribadi. Selain itu dalam model tersebut terdapat environment information yang mempengaruhi motivasi, seperti pengetahuan, sosial budaya, dan faktor-faktor situasional lainnya. Dalam kaitan dengan petani, bahwa environment information dapat berupa pengetahuan tentang lingkungan hidup dan kearifan lokal masyarakat setempat.

\section{Kesimpulan}

Berdasarkan hasil analisis data dan perhitungan statistik seperti yang diuraikan diatas, maka dari penelitian ini diperoleh temuan sebagai berikut:

1. Pengetahuan tentang lingkungan hidup berpengaruh langsung positif terhadap motivasi bertani. Hal ini berarti tinggi rendahnya motivasi bertani salah satunya dipengaruhi oleh pengetahuan tentang lingkungan hidup. Dengan demikian, pengetahuan tentang lingkungan hidup menyebabkan perubahan terhadap motivasi bertani.

2. Pengetahuan tentang lingkungan hidup berpengaruh langsung positif terhadap perilaku lingkungan yang bertanggung jawab petani. Hal ini berarti tinggi rendahnya perilaku lingkungan yang bertanggung jawab petani salah satunya dipengaruhi oleh pengetahuan tentang lingkungan hidup. Dengan demikian, pengetahuan tentang lingkungan hidup menyebabkan perubahan terhadap perilaku lingkungan yang bertanggung jawab petani.

3. Kearifan lokal berpengaruh langsung positif terhadap motivasi bertani. Hal ini berarti tinggi rendahnya motivasi bertani salah satunya dipengaruhi oleh kearifan lokal. Dengan demikian, kearifan lokal
Volume XVI 
menyebabkan perubahan terhadap motivasi bertani.

4. Kearifan lokal berpengaruh langsung positif terhadap perilaku lingkungan yang bertanggung jawab petani. Hal ini berarti tinggi rendahnya perilaku lingkungan yang bertanggung jawab petani salah satunya dipengaruhi oleh kearifan lokal. Dengan demikian, kearifan lokal menyebabkan perubahan terhadap perilaku lingkungan yang bertanggung jawab petani.

5. Locus of control berpengaruh langsung positif terhadap motivasi bertani petani. Hal ini berarti tinggi rendahnya motivasi bertani salah satunya dipengaruhi oleh locus of control. Dengan demikian, locus of control menyebabkan perubahan terhadap motivasi bertani.

6. Locus of control berpengaruh langsung positif terhadap perilaku lingkungan yang bertanggung jawab petani. Hal ini berarti tinggi rendahnya perilaku lingkungan yang bertanggung jawab petani salah satunya dipengaruhi oleh locus of control. Dengan demikian, locus of control menyebabkan perubahan terhadap perilaku lingkungan yang bertanggung jawab petani.

7. Motivasi bertani berpengaruh langsung positif terhadap perilaku lingkungan yang bertanggung jawab petani. Hal ini berarti tinggi rendahnya perilaku lingkungan yang bertanggung jawab petani salah satunya dipengaruhi oleh motivasi bertani. Dengan demikan, motivasi bertani menyebabkan perubahan terhadap perilaku lingkungan yang bertanggung jawab petani.

8. Pengetahuan tentang lingkungan hidup berpengaruh tidak langsung melalui motivasi bertani terhadap perilaku lingkungan bertanggung jawab petani. Hal ini berarti tinggi rendahnya perilaku lingkungan yang bertanggung jawab petani dipengaruhi oleh pengetahuan tentang lingkungan hidup dan motivasi bertani. Dengan demikian, pengetahuan tentang lingkungan hidup menyebabkan perubahan terhadap perilaku lingkungan bertanggung jawab petani melalui motivasi bertani.

9. Kearifan lokal berpengaruh tidak langsung melalui motivasi bertani terhadap perilaku lingkungan yang bertanggung jawab petani. Hal ini berarti tinggi rendahnya perilaku lingkungan yang bertanggung jawab petani dipengaruhi oleh karifan lokal melalui motivasi bertani Dengan demikian kearifan lokal menyebabkan perubahan terhadap perilaku lingkungan bertanggung jawab petani melalui motivasi bertani.

10. Locus of control berpengaruh tidak langsung melalui motivasi bertani terhadap perilaku lingkungan yang bertanggung jawab petani. Hal ini berarti tinggi rendahnya perilaku lingkungan yang bertanggung jawab petani dipengaruhi oleh locus of control melalui motivasi bertani. Dengan demikian, locus of control menyebabkan perubahan terhadap perilaku lingkungan bertanggung jawab petani melalui motivasi bertani.

Berdasarkan temuan-temuan di atas, maka dapat disimpulkan bahwa perilaku lingkungan yang bertanggung jawab petani dipengaruhi secara langsung dan tidak langsung oleh pengetahuan tentang lingkungan hidup, kearifan lokal, locus of control dan motivasi bertani, baik secara sendiri-sendiri maupun secara bersama-sama.

\section{Volume XVI}

Nomor 02
September 2015

ISSN 1411-1829 
Perkembangan ilmu pengetahuan dan teknologi berdampak pada meningkatnya pembangunan di segala bidang, termasuk pembangunan bidang pertanian. Peningkatan produksi pertanian dengan penerapan teknologi telah membawa perubahan besar, baik terhadap peningkatan produksi pertanian maupun terhadap lingkungan.

Perubahan lingkungan yang sangat dirasakan adalah krisis lingkungan terutama pada lahan-lahan pertanian. Hal ini sebagai akibat dari perilaku lingkungan yang bertanggung jawab petani yang cenderung negatif. Perilaku lingkungan yang bertanggung jawab petani dalam mengolah lahan pertanian merupakan aktivitas yang dilakukan dalam pemanfaatan sumber daya, pemeliharaan lingkungan dan penggunaan produk ramah lingkungan.

Perilaku lingkungan yang bertanggung jawab petani dapat diwujudkan, jika petani: mengetahui arti pentingnya lingkungan hidup, dapat mengaplikasikan bentuk-bentuk kearifan lokal yang diterima secara turuntemurun, mampu menilai keberhasilan dan kegagalannya atas kegiatan yang dilakukan, serta adanya motivasi yang tinggi dalam bertani.

Tuntutan peningkatan perilaku lingkungan yang bertanggung jawab petani sangat penting dalam mewujudkan pembangunan pertanian berkelanjutan. Perilaku lingkungan yang bertanggung jawab petani diketahui dipengaruhi berbagai aspek, seperti pengetahuan tentang lingkungan, kearifan lokal, locus of control, dan motivasi bertani.

Penelitian ini memberikan dampak terhadap perkembangan khasanah ilmu pengetahuan terutama teoretik, Hal ini memperkaya generalisasi tentang berbagai variabel yang diajukan dalam model teoretik perilaku lingkungan yang bertanggung jawab. Konsistensi model teoretik perilaku lingkungan yang bertanggung jawab menunjukkan variabel eksogenous yaitu: pengetahuan tentang lingkungan hidup, kearifan lokal, locus of control, dan motivasi bertani dapat menjadi acuan dalam pembangunan pertanian berkelanjutan.

Perilaku lingkungan yang bertanggung jawab petani dapat ditingkatkan dengan meningkatkan pengetahuan tentang lingkungan hidup, kearifan lokal, locus of control, dan motivasi bertani. Kebijakan dalam rangka meningkatkan perilaku lingkungan yang bertanggung jawab petani dapat didasarkan pada variabel pengetahuan tentang lingkungan hidup, kearifan lokal, locus of control, dan motivasi bertani.

Penelitian ini memperkuat pengetahuan dan teori bahwa variabel perilaku lingkungan yang bertanggung jawab dipengaruhi oleh berbagai variasi dari variabel eksogen. Jika merujuk pada model teoretik yang diajukan dan berdasarkan temuan penelitian, maka peningkatan perilaku lingkungan yang bertanggung jawab petani perlu dipertimbangkan dengan memperhatikan pengetahuan tentang lingkungan hidup, kearifan lokal, locus of control dan motivasi bertani.

Penelitian ini masih memerlukan penelitian lanjutan yang lebih komprehensif dengan berdasarkan pada temuan penelitian yang diperoleh. Selain itu perlu penelitian dengan mempertimbangkan variabel lain yang mempengaruhi variabel endogenous

\section{Daftar Pustaka}

Ancok, D. 1997. Teknik Penyusunan Skala Pengukuran. Pusat Penelitian Kependudukan Universitas Gadjah Mada. Yogyakarta.

Anderson L. W. and Krathwohl, David R., A Taksonomy for Learning, 
Teaching and Assessing A Revision of Educational Objectives, New York: Eddison Wesley Longman, inc, 2001.

Andre, Rae, Organizational Behavior An Introduction to Your Life in Organizations, Singapore: Pearson Prentice Hall, 2008.

Anon, Undang-Undang Nomor 32 Tahun 2009 tentang Perlindung-an dan Pengelolaan Lingkungan Hidup, Jakarta: Kementerian Lingkungan Hidup, 2009.

, Kabupaten Soppeng dalam Angka, Badan Pusat Statistik Soppeng, 2008.

Berliner, David C. and Robert C. Calfee, Hull's Drive Theory, in Hand Book of Educational Psychology.New York: Prentice Hall International, 1996.

Bloom, Benjamin S., (ed.) Taxonomy of Educational Objectives Book I Cognitive Domain. London: Longman Ltd, 1979.

Branden, Nathanniel, Self-Relience and the Accountable Life;Taking Responsibility. New York: Simon \& Schuster Rockelfeller Center, 1996.

Carry, John, The Natural of Simbolic; Beliefs, and Environment Behaviour in A Rural Setting, Environment and Behaviour, London: Sage Publications, Inc., Vol. 25 September. 1993.

Chiras, Environmental Science Action for a Sustainable Future. Redwood City, California: Cumming Publishing Company Inc., 1991.

Ciran, Indigenous knowledge for Environment. p.3, 2006 (http:// www.nufficcs.nl/ciran/ik-pages/)
Conant, James B., "Apakah Ilmu Pengetahuan itu?" Ilmu Pengetahuan dan Metodenya, Terjemahan Basco Carvalla, Sonny Keraf, dan Andre Ata Ujan, Jakarta: Yayasan Obor Indonesia, 1995.

Corsini, R.J., Marsella, A.J., Personality Theories: Research and Assesment. USA: University of Hawai at Manoa-Peacock Published, Inc., 1983.

Crano, Willian D., and Messe, Laurance A. Social Psychology Principle and Theme of Interpersonal Behavior, Home World: Dorsey Press, 1982.

Etienne de Sevin and Daniel Thalmann, "A Motivational Model of Action Selection for Virtual Humans". 2005. (http://vrlab.epfl.ch/esevin/CGI)

Gibson, J.L., Ivancevich, J.M., \& Donnelly, J.H., Organizations, Behavior, Structure, dan Process, New York: New York: The McGraw-Hill, 2006.

Good Thomas L. \& Jere E. Brophy, Educational Psychology: A Realistic Approach. New York: Longman, 1990.

Hungerford, H.R., \& Volk, T.L., Changing Learner Behavior Through Environmental Education, The Journal of Environmentaly Education, Vol, 21 (3) Spring. 1990.

Karwan, A. Salikin, Sistem Pertanian Berkelanjutan. Yogyakarta: Karnisius, 2003.

Keraf, A.S. Etika Lingkungan. Teoriteori Etika Lingkungan dan Politik Lingkungan. Dari Ilmu Pengetahuan dan Teknologi Modern dan Kembali Ke 
Kearifan Tradisional. Jakarta: Penerbit Buku Kompas, 2006.

Koivisto, Marketta. Factors Influencing Environmentally Responsible Behavior in the Finnish Service Sector, Helsingki: Helsingki University of Tecnology, 2008.

Larsen, R.J., Bush, D.M., Personality Psychology: Domains of Knowledge about Human Nature. International Edition. NY: The McGraw-Hill, 2002.

Martin, Gery and Pear, Joseph. Behavior Modification. New Jersey: Prentice Hall International, Inc., 1992.

Odum E.P. Fundamental of Ecology Third Edition, Edisi Indonesia: Dasar-Dasar Ekologi, Diterjemahkan oleh Tjahjono Samingan, Yogyakarta: Gajah Mada University Press, 1994.

Pervin, Lawrence $A$ and, Oliver, $P$. John, Personality Theory and Research. USA: John Willey and Sons, Inc., 1997.

Robbins, Stephen P. Management. Englewood Cliffs, New Jersey; Printice Halll Inc. 1994.

Rukminto, Isbandi, Psikologi, Pekerjaan Sosial, dan Ilmu Kesejahteraan Sosial: Dasar-dasar Pemikiran, Jakarta: Grafindo Persada, 1994.

Rustanto B, Kesejahteraan Sosial Berbasis Kearifan Lokal bagi Komunitas Adat Terpencil, 2009. (http:/ bambangrustanto. blog spot.com/2009)

Salam B., Etika Sosial, Azas Moral dalam Kehidupan Manusia, Jakarta: Rineka Cipta, 1992.

Salim, Emil, Lingkungan Hidup dan Pembangunan, Jakarta: Mutiara Sumber Wijaya, 1985.
Pembangunan Berwawasan Lingkungan. Jakarta: LP3ES, 1986.

Slocum, John W. Jr. and Hellriegel, Don, Principles of Organizati-onal Behavior, New York: Cengage Learning, 2009.

Sternberg, R.J., Why Schools Teach for Wisdom: The Balance Theory of Wisdom in Educa-tional Setting Educational Psychologyst, 2001.

Suratiyah K, Ilmu Usaha Tani, Jakarta: Penebar Swadaya, 2009.

Tiezzi, E., Marchettini, T., \& Rossini, M. TT., Extending the Environmental Wisdom beyond the Local Scenario, (http://library. witpress.com/paperinfo. asp.)

Vaughan, Graham, Michael Hogg, Introduction so Social Psychology, Sydney: Prentice Hall, 1995.

Vroom, Victor H., Work and Motivation, New York: Wiley, 2008, (http://wordpress.com/ teoriteori-motivasi).

Wahosumidjo, Kepemimpinan dan Motivasi, Jakarta: Ghalia Indonesia, 1992.

Walgito, B. Pengantar Psikologi Umum, Yogyakarta: Andi Offset, 1993.

Wingkel, W.S., Psikologi Pengajaran, Jakarta: Grafindo, 1996.

Woolfolk, A., Educational Psychology Active Learning Edition, Diterjemahkan Helly Prajitno S. dan Sri Mulyantini S, Yogyakarta: Pustaka Pelajar, 2009. 
